\title{
Faktor Penyebab Keterlambatan Pengembalian Dokumen Rekam Medis di RS X Kabupaten Kediri
}

\author{
Sayyidah Mirfat*, Nurwulan Andadari, Yetty Nusaria Nawa Indah \\ * Penulis Korespondensi: sayyidah.mirfat11@gmail.com
}

* Rumah Sakit Umum Islam Madinah Kasembon Malang, Jawa Timur, Indonesia

\begin{tabular}{l}
\hline $\boldsymbol{I} \boldsymbol{N D E} \boldsymbol{X} \boldsymbol{I} \boldsymbol{N} \boldsymbol{G}$ \\
\hline Keywords: \\
Medical record; delays \\
return; factors;
\end{tabular}

Kata kunci:

Rekam medis; keterlambatan pengembalian; faktorfaktor;

\begin{abstract}
A B S T R A C T
The purpose of this study was to determine the root problem of any late return of inpatient medical records documents in $X$ Hospital. This research was conducted with a qualitative descriptive approach with the method of observation, in-depth interviews and time motion study. Determining root of the problem is done by brainstorming with the hospitals staff with USG method (urgency, seriousness, growth). Root problem that contribute to delay return of inpatient medical records are indiscipline doctor in filling out medical records especially medical resumes; some doctor are not making patient visit every day, so the order was given by phone; and sometime nurses forgot to remind the doctor to fill out a medical resume and signature. Other factors affecting the delay are method, money, material dan machine factors.
\end{abstract}

Tujuan dari penelitian ini adalah untuk mengetahui akar masalah keterlambatan pengembalian dokumen rekam medis rawat inap di RS X. Penelitian ini dilakukan dengan pendekatan deskriptif kualitatif dengan metode observasi, wawancara mendalam, serta time motion study. Pencarian akar masalah dilakukan dengan cara brainstorming dengan pihak rumah sakit dengan metode USG (urgency, seriousness, growth). Faktor utama penyebab keterlambatan pengembalian DRM rawat inap adalah faktor SDM (sumber daya manusia) yaitu ketidakdisiplinan DPJP (dokter penanggungjawab pelayanan) dalam pengisian rekam medis terutama resume medis, beberapa DPJP tidak visite setiap hari sehingga advis pulang per telepon dan perawat lupa mengingatkan dokter untuk mengisi resume medis dan tanda tangan. Faktor lain yang mempengaruhi keterlambatan antara lain faktor method, money, material dan machine

(C) 2017 JMMR. All rights reserved

\section{PENDAHULUAN}

Rekam medik yang lengkap adalah rekam medik yang telah diisi lengkap oleh dokter dalam waktu kurang dari 24 jam setelah selesai pelayanan rawat jalan atau setelah pasien rawat inap diputuskan untuk pulan. Pengembalian dokumen rekam medis dinyatakan terlambat apabila melebihi batas waktu pengembalian yaitu maksimal $2 \times 24$ jam setelah pasien keluar dari rumah sakit. Keterlambatan ini akan menghambat pelaksanaan tugas bagian assembling rekam medis yang dapat berdampak pada terhambatnya pelayanan pasien. Bagian assembling memiliki tugas untuk merakit dokumen rekam medis, meneliti isi rekam medis termasuk kelengkapan penulisannya, mengendalikan dokumen rekam medis yang tidak lengkap serta mengendalikan penggunaan formulir rekam medis. ${ }^{1}$

Penelitian yang dilakukan oleh Rachmani menunjukkan bahwa keterlambatan pengembalian dokumen rekam medis ke bagian assembling di RS Tentara dan POLRI Semarang sebesar 95,10\%. Data yang didapat yaitu rata-rata kembalinya dokumen rekam medis (DRM) adalah
5 hari, paling cepat 3 hari dan paling lama 159 hari. Penyebab keterlambatan terbesar yaitu anggapan responden bahwa pelayanan di rawat inap lebih penting daripada mengembalikan DRM ke assembling dan jauhnya jarak antara ruang rawat inap dengan bagian assembling. ${ }^{2}$

Rumah Sakit X merupakan salah satu rumah sakit umum tipe $\mathrm{C}$ yang ada di kabupaten Kediri. Rumah sakit ini mempunyai kapasitas tempat tidur pasien sebanyak 160 TT (tempat tidur) dan sudah terakreditasi KARS (Komisi Akreditasi Rumah Sakit) versi 2012 dengan predikat kelulusan paripurna. Indikator kinerja rumah sakit pada tahun 2016 (sampai dengan bulan Juni 2016) meliputi Bed Occupancy Rate (BOR) sebesar 96,70\%, Average Length of Stay (ALOS) 4,16 hari, Turn Over Interval (TOI) 0,14 hari, Bed Turn Over (BTO) 42,34 kali, Gross Death Rate (GDR) 45,85 permil dan Nett Death Rate (NDR) 23,24 permil.

Hasil studi pendahuluan di RS X melalui data sekunder dan wawancara dengan staf rekam medis maupun staf keperawatan menunjukkan bahwa rata-rata pengembalian dokumen rekam medis rawat inap dari ruang 
rawat inap ke bagian rekam medis di tahun 2016 adalah lebih dari tujuh hari. Hal ini jauh dari standar yang diharapkan yaitu kurang dari $2 \times 24$ jam. Dari hasil wawancara dengan bagian rekam medis dan staf keperawatan menunjukkan bahwa lamanya pengembalian dipengaruhi oleh kurang lengkapnya pengisian data rekam medis oleh dokter.

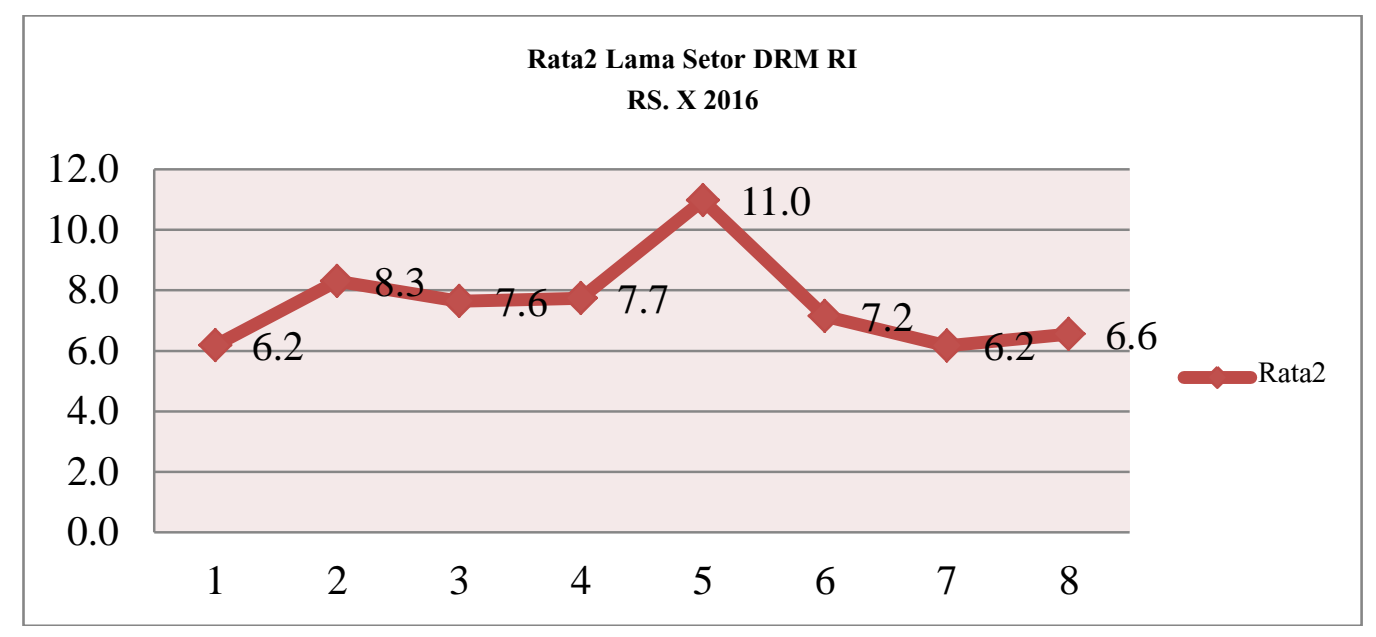

Gambar 1. Rata-Rata Lama Setor Dokumen Rekam Medis Rawat Inap di RS X Januari-Agustus 2016 Sumber : Laporan Bulanan Rekam Medis, 2016.

Selain melakukan wawancara dengan staf keperawatan dan staf rekam medis, observasi awal juga dilakukan dengan mengamati alur rekam medis rawat inap saat pasien pulang. Pada observasi awal tersebut, hampir di seluruh ruangan perawat di ruang rawat inap ditemukan tumpukan rekam medis pasien pulang. Saat wawancara dengan perawat diketahui bahwa rekam medis tersebut bukan hanya milik pasien yang baru diperbolehkan pulang, tetapi juga milik pasien yang sudah pulang lebih dari empat hari. Kebanyakan berkas rekam medis tersebut merupakan milik pasien yang advis pulangnya oleh DPJP (dokter penanggung jawab pelayanan) diberikan lewat telepon. Sehingga resume medis belum diisi lengkap terutama bagian diagnosis utama dan tanda tangan. Oleh karena itu, penelitian ini dilakukan untuk mengetahui lebih lanjut akar masalah keterlambatan pengembalian dokumen rekam medis rawat inap di RS X.

\section{LITERATUR DAN FOKUS PENELITIAN}

\section{Tinjauan Umum Rekam Medis}

Rekam medis adalah suatu berkas yang berisi catatan dan dokumen kesehatan seseorang yang terdiri dari identitas pasien, hasil pemeriksaan baik pemeriksaan fisik maupun pemeriksaan penunjang, pengobatan, tindakan dan pelayanan lain yang diberikan oleh tenaga kesehatan kepada pasien. $^{3}$

Rekam medis ada dua macam yaitu berbasis kertas (paper based medical records) dan berbasis elektronik (electronic medical records / EMR). EMR adalah rekam medis yang disimpan dalam media elektronik seperti komputer digital. Rekam medis memiliki manfaat antara lain untuk dasar pengobatan kepada pasien, peningkatan kualitas pelayanan, pendidikan dan penelitian, pembiayaan, perhitungan statistik kesehatan serta untuk pembuktian jika terjadi masalah hukum, disiplin dan etik yang berkaitan dengan tenaga kesehatan. ${ }^{4}$ Kualitas pelayanan rekam medis menjadi salah satu tolak ukur mutu pelayanan rumah sakit. Salah satu parameter untuk menilai mutu pelayanan kesehatan di rumah sakit yaitu dengan menilai data dan informasi yang tersedia dalam dokumen rekam medis. Indikator rekam medis yang baik dan lengkap yaitu kelengkapan isi, akurat, tepat waktu dan pemenuhan aspek persyaratan hukum. ${ }^{5}$

Seorang dokter atau dokter gigi yang tidak membuat rekam medis dapat terkena sanksi secara hukum maupun etika dan disiplin profesi. Menurut Undang-Undang Praktik Kedokteran setiap dokter atau dokter gigi yang dengan sengaja tidak membuat rekam medis dapat dihukum dengan pidana kurungan paling lama satu tahun dan denda paling banyak 50 juta rupiah. Selain itu sanksi perdata juga dapat diberikan karena tidak melakukan yang seharusnya 
dilakukan (ingkar janji/ wanprestasi) dalam hubungannya dengan pasien. ${ }^{4}$

Rekam medik yang lengkap adalah rekam medik yang telah diisi lengkap oleh dokter dalam waktu kurang dari $\leq$ 24 jam setelah selesai pelayanan rawat jalan atau setelah pasien rawat inap diputuskan untuk pulang, yang meliputi identitas pasien, anamnesa, rencana asuhan, pelaksanaan asuhan, tidak lanjut dan resume medis. ${ }^{6}$ Pengembalian dokumen rekam medis dinyatakan terlambat apabila melebihi batas waktu pengembalian yaitu maksimal $2 \times 24$ jam setelah pasien keluar dari rumah sakit. Keterlambatan ini akan menghambat pelaksanaan tugas bagian assembling rekam medis yang dapat berdampak pada terhambatnya pelayanan pasien. Bagian assembling memiliki tugas untuk merakit dokumen rekam medis, meneliti isi rekam medis termasuk kelengkapan penulisannya, mengendalikan dokumen rekam medis yang tidak lengkap serta mengendalikan penggunaan formulir rekam medis. ${ }^{1}$

\section{Faktor-faktor yang Mempengaruhi Keterlambatan Penyerahan Dokumen Rekam Medis Rawat Inap}

Penelitian yang dilakukan oleh Rachmani di Rumah Sakit POLRI dan TNI Semarang menunjukkan bahwa banyak faktor yang mempengaruhi keterlambatan penyerahan dokumen rekam medis (DRM) rawat inap dari bangsal ke bagian assembling. Faktor yang mempengaruhi keterlambatan ini antara lain belum adanya protap pengembalian dokumen rekam medis dari ruang rawat inap ke bagian assembling, tidak adanya petugas rekam medis di ruangan yang meneliti kelengkapan dokumen rekam medis, jarak ruang rawat inap ke ruang rekam medis yang jauh, belum lengkapnya atau tidak lengkapnya dokumen rekam medis terutama tanda tangan dokter sehingga DRM rawat inap tidak dapat diserahkan dalam waktu $2 \times 24$ jam. ${ }^{1}$

Keterlambatan pengembalian DRM rawat inap ke bagian assembling dapat mengganggu pelayanan, terutama jika dokumen tersebut dibutuhkan saat pasien kontrol di rawat jalan atau jika pasien rawat inap kembali. Petugas assembling menilai kelengkapan DRM yang dikembalikan, jika dinilai tidak lengkap maka DRM akan dikembalikan ke ruang rawat inap untuk dilengkapi dalam jangka waktu $2 \times 24$ jam. Keterlambatan ini tentu akan mengganggu kontinuitas pelayanan.

Penelitian lain yang dilakukan oleh Lihawa menunjukkan bahwa ketidaklengkapan dokumen rekam medis rawat inap merupakan masalah yang sering terjadi di rumah sakit. Faktor penyebab ketidaklengkapan pengisian rekam medis antara lain: kurang adanya sosialisasi mengenai SPO dan kebijakan tentang rekam medis terutama kepada para dokter spesialis; dokter belum mengetahui bahwa rekam medis harus diisi lengkap $\leq 24$ jam setelah pasien rawat inap diputuskan pulang; susunan form rekam medis yang tidak sistematis; rapat yang membahas kelengkapan dokumen rekam medis kurang efektif karena tidak melibatkan dokter spesialis; serta kepala ruangan atau perawat tidak selalu mengingatkan dokter untuk melengkapi rekam medis. ${ }^{5}$

Menurut Pamungkas, penyebab ketidaklengkapan DRM adalah kurang disiplinnya dokter dalam pengisian rekam medis. Dokter lebih memprioritaskan pelayanan sehingga waktu yang dialokasikan untuk pengisian dokumen rekam medis sedikit yang berakibat pada ketidaklengkapan dokumen rekam medis. Faktor lain yaitu: kurangnya kesadaran dokter akan pentingnya pengisian rekam medis; belum maksimalnya monitoring dan evaluasi kelengkapan rekam medis; belum adanya pencatatan KTD dan KNC akibat ketidaklengkapan DRM; form rekam medis yang terlalu banyak jenisnya; serta terbatasnya dukungan dana dari manajemen terkait kelengkapan rekam medis. ${ }^{7}$ Padahal rekam medis sangat penting baik bagi pasien, tenaga kesehatan maupun bagi fasilitas kesehatan.

Rekam medis di era JKN menjadi sesuatu yang sangat penting karena menjadi penentu dalam perhitungan biaya untuk klaim. Menurut Pujihastuti, terdapat 65\% rumah sakit yang belum membuat diagnosis yang lengkap dan jelas di antara rumah sakit yang sudah bekerjasama dengan BPJS. Penelitian tersebut mendapatkan hasil bahwa 30\% rekam medis yang diteliti pengisian informasinya tidak lengkap, sedangkan keakuratan kode diagnosisnya mencapai $70 \%$ yang dipengaruhi kelengkapan pengisian informasi diagnosis pada dokumen rekam medis. ${ }^{8}$

Penelitian lain yang dilakukan oleh Febriyanti memberikan hasil bahwa pengisian dokumen rekam medis di RSUD dr. Slamet Garut masih belum sesuai dengan prosedur yang ditetapkan oleh rumah sakit khususnya yang berkaitan dengan identifikasi pasien, laporan penting, autentikasi dan pencatatan. Kelengkapan identifikasi pasien hanya mencapai $20 \%$, kelengkapan pengisian data laporan penting pasien sebesar $31,12 \%$, dan kelengkapan pengisian data autentikasi yaitu $83,33 \%$. RSUD dr. Slamet Garut sudah bekerjasama dengan

\section{METODE PENELITIAN}

Penelitian ini dilakukan sejak tanggal 16 Agustus 2016 - 21 Oktober 2016 secara deskriptif kualitatif dengan metode observasi, wawancara mendalam, serta time motion 
study. Wawancara mendalam dilakukan kepada satu dokter spesialis, satu dokter ruangan, kepala sub divisi rekam medis, kepala sub divisi keperawatan ruang rawat inap 1-6, perawat ruang intensive care unit (ICU), bidan ruang VK (Verlos Kamer) / kamar bersalin, dan petugas verifikasi. Pengamatan (observasi) dan wawancara merupakan dua teknik pengumpulan data (alat ukur) yang utama dalam penelitian kualitatif, karena mempunyai kesahihan dan keandalan yang tinggi dan mampu menjaring data verbal dan nonverbal tentang aspek perilaku manusia. ${ }^{10}$

Penentuan penyebab masalah digali melalui metoda curah pendapat (brainstorming) dan jangan menyimpang dari masalah. Untuk menentukan kemungkinan penyebab masalah dapat menggunakan diagram tulang ikan (fishbone) atau disebut juga dengan diagram Ishikawa.11 Dari diagram fishbone ditemukan lima kelompok faktor yaitu man, material, method, money dan machine. Brainstorming bersama pembimbing lapangan, staf rekam medis, staf keperawatan, verifikator BPJS (Badan Penyelenggara Jaminan Sosial) dan dokter dilakukan tanggal 3 Oktober 2016 untuk mengetahui akar masalah yang paling berkontribusi. Dari kelima faktor tersebut lalu digunakan metode Urgency, Seriousness, Growth (USG) untuk menentukan faktor terbesar penyebab kendala tersebut. $^{7}$

\section{HASIL DAN PEMBAHASAN}

Wawancara dengan kepala ruangan rawat inap dan staf perawat rawat inap menunjukkan bahwa keterlambatan pengembalian DRM rawat inap ke bagian rekam medis merupakan masalah yang muncul di RS X terutama setelah RS X bekerjasama dengan BPJS. Rekam medis pasien swasta lebih cepat kembali ke bagian rekam medis karena tidak perlu melewati verifikasi. Setelah pasien dinyatakan boleh pulang, resume medis dapat dilengkapi oleh dokter ruangan jika DPJP (dokter penanggungjawab pelayanan) berhalangan.

\section{Faktor Sumber Daya Manusia}

Kurangnya Kedisiplinan Dokter dalam Pengisian Rekam Medis terutama Resume Medis

FGD (focus group discussion) yang dilakukan pada tanggal 3 Oktober 2016 dan wawancara kepada perawat ruang rawat inap menunjukkan bahwa faktor utama penyebab keterlambatan pengembalian DRM rawat inap adalah dari sisi dokter. DPJP di RS X kurang displin dalam pengisian rekam medis terutama resume medis. DPJP mengisi asesmen awal medis dan catatan terintegrasi, tetapi ketika pasien akan pulang resume medis sering belum dilengkapi.

"Biasanya itu mbak ya..paling banyak itu resume belum diisi, terus tanda tangan dokternya juga susah" (A/R/25082016/1000).

"Terus kalau dokter spesialisnya mannya cuma nulis diagnosa ini saja, yang lainnya yang melengkapi akhirnya dokter ruangan dibantu sama kasubdiv" (B/S/26082016/1114).

“Wong kadang itu ya, dok besok mau libur dua hari, minta tandatangan dulu, terus dokternya bilang kan belum ada rencana pulang. Dokternya bilang besok aja mbak kalau udah pasti pulang”(C/D/23092016/1127).

"Ada beberapa dokter juga yang suka menunda-nunda, meskipun sudah dikasitau kalau ada PR tapi bilange, sek talah sus, mben-mben sek ae, aku selak nang poli iki lho. Pokoknya ya yang paling sering ya kurang tandatangan sama diagnosa di resume itu" (E/B/22092016/1230).

Hasil observasi di ruang rawat inap terlihat penumpukan dokumen rekam medis. Rekam medis tersebut bukan hanya milik pasien yang baru diperbolehkan pulang, tetapi juga milik pasien yang sudah pulang lebih dari empat hari. Kebanyakan berkas rekam medis tersebut merupakan milik pasien yang advis pulangnya oleh DPJP diberikan lewat telepon. Sehingga resume medis belum diisi lengkap terutama bagian diagnosis utama dan tanda tangan. Selain itu setelah pasien pulang, dokumen rekam medis tidak langsung dilengkapi baik oleh perawat maupun oleh DPJP. DPJP yang visite langsung akan menandatangani resume medis, tetapi hanya beberapa dokter yang menulis lengkap resume medisnya. Kebanyakan DPJP hanya menulis diagnosis utama dan memberikan tanda tangan. Perawat jaga menumpuk DRM rawat inap pasien yang sudah pulang, dan keesokan harinya kepala ruang akan membantu melengkapi dan menandai bagian yang belum lengkap.

\section{Beberapa DPJP Tidak Visite Setiap Hari, Sehingga Advis Pulang per Telepon}

DPJP di RS X sebagian besar merupakan dokter tamu, sehingga tidak selalu visite setiap hari. Jika DPJP berhalangan maka advis pulang akan diberikan per telepon. Penulisan resume medis dan tanda tangan akan diberikan ketika DPJP visite atau ada jadwal di poliklinik. Dokter spesialis juga kebanyakan terburu-buru saat visite sehingga menunda-nunda pengisian rekam medis, karena sudah ditunggu banyak pasien di poliklinik. 
"Gini lho dok, ruang sini kan pasiennya banyak, terus penuh-penuh. Jarang banget kosong, terus pasien sekali pulang gitu langsung banyak, padahal kadang itu advis pulangnya per telepon" (C/D/26082016/1300).

"Dokternya kan ada yang gak tiap hari visite, jadinya kadang advis pulang itu dikasi per telepon" (D/M/22092016/1200).

"Selain itu kadang jumat cuman ngasi advis per telepon, sudah bisa pulang ini, terus sabtunya kita mau minta resume gak bisa soalnya sabtunya gak visite” (C/D/23092016/1127).

"Kadang dokter pas gak visite advis pulangnya per telepon kan akhirnya baru bisa ketemu dokternya pas visit lagi atau poli dok, jadi rekam medisnya numpuk” (J/D/21102016/1253).

"Karena kebanyakan dokter itu pas visite terburu-buru soalnya kan kebanyakan sudah ditunggu pasien di poli" (E/B/22092016/1230).

\section{Perawat Lupa Mengingatkan Dokter untuk Mengisi Resume Medis dan Tandatangan}

RS X memiliki BOR yang cukup tinggi yaitu 96,70\% dan sebagian besar pasiennya merupakan pasien BPJS. Beban kerja tenaga kesehatan terutama perawat menjadi tinggi. Menurut sebagian besar kepala ruang rawat inap, tenaga perawat yang dimiliki masih kurang terutama di ruang kelas II dan III. Perawat lebih fokus pada pelayanan sehingga saat DPJP visite kadang perawat lupa mengingatkan dokter untuk melengkapi rekam medis yang sudah ditandai sebelumnya.

"Kadang juga perawatnya lupa gak ngingetkan dokter buat tanda tangan sama nulis resume” (E/B/22092016/1230).

"Faktor dari perawatnya yang kadang-kadang kita juga lupa buat mengingatkan” (E/B/22092016/1230).

"Terus perawatnya juga lupa gak mengingatkan. Terus paling sering ya advis pulang lewat telepon itu" (B/S/24092016/1250).

\section{Beban Kerja Dokter dan Perawat Tinggi Karena Peningkatan BOR}

Setelah dokumen rekam medis dinilai lengkap oleh kepala ruangan maka DRM rawat inap tersebut akan disetorkan ke bagian rekam medis. Penyetoran ini dilakukan oleh perawat jaga atau oleh petugas kurir untuk beberapa ruang rawat inap. Perawat jaga akan mengantar DRM ini jika sedang longgar yang artinya pekerjaan di pelayanan bisa ditinggalkan. Rekam medis yang sudah lengkap pada sore hari baru akan disetorkan keesokan harinya. Belum adanya petugas khusus administrasi di ruang rawat inap, khususnya untuk mengantar dokumen rekam medis ke bagian assembling rekam medis dianggap oleh perawat menjadi salah satu akar masalah penyebab keterlambatan pengembalian DRM rawat inap ke rekam medis.

Observasi di ruangan rawat inap juga dilakukan untuk mengetahui beban kerja perawat dalam pengisian rekam medis. Selama observasi, perawat terlihat sibuk memberikan pelayanan kepada pasien. Kepala ruangan lebih banyak mengurusi masalah dokumen, sedangkan pelayanan ditangani oleh perawat jaga. Untuk ruangan kelas VIP (very important person) dan kelas 1, rasio perawat dan pasien masih mencukupi. Tetapi untuk ruangan kelas II dan kelas III, terutama karena lebih sering penuh, sehingga beban kerja perawat cukup tinggi. Kelas 3 memiliki kapasitas tempat tidur (TT) sejumlah 39 TT, dengan jumlah perawat 15 . Setiap shift jaga dijaga oleh 3-4 perawat, sehingga setiap perawat bertanggung jawab terhadap 10-13 pasien. Kesibukan ini sangat terlihat terutama di ruang kelas III, saat observasi selama 1 jam di ruang rawat inap kelas 3 pada pagi hari, tidak terlihat ada perawat yang menganggur. Satu orang perawat berkeliling dari satu pasien ke pasien lain untuk memeriksa TTV (tanda tanda vital), dua orang mengerjakan dokumentasi, dan kepala perawat mengorganisir dokumen rekam medis pasien yang sudah pulang dan melengkapinya.

\section{Faktor Metode}

\section{Ketidakpastian Jam Visite Dokter Spesialis}

DPJP di RS X kebanyakan visite saat ada jam poliklinik. DPJP kadang berhalangan hadir terutama di hari Sabtu dan Minggu karena kadang ada jadwal seminar terkait profesinya. Ketidakpastian jam visite terutama untuk dokter tamu juga menjadi masalah yang memperlama pengembalian DRM rawat inap. DPJP kadang visite sebelum atau sesudah jadwal poliklinik, terkadang juga visite malam hari. Ketidakpastian ini membuat perawat tidak dapat mempersiapkan DRM yang belum lengkap.

"Jadinya seringnya itu jam visitnya gak pasti, selonggarnya beliau. Kadang sebelum poli, sesudah poli, atau kadang ada yang pas ga ada jadwal poli tapi ada pasien, ya kadang jamnya selonggarnya beliau. Apalagi hari Sabtu, dokter kebanyakan seminar kalau pas Sabtu, jadinya ya gak visit", (C/D/26082016/1300). 


\section{DRM Pasien BPJS Harus Masuk ke Verifikasi}

Berkas rekam medis pasien BPJS harus melewati bagian verifikasi dulu sebelum diserahkan ke bagian rekam medis. Alur dokumen ini belum sesuai dengan alur rekam medis dari Departemen Kesehatan, karena seharusnya rekam medis pasien rawat inap yang sudah pulang seharusnya dikembalikan ke bagian rekam medis dalam waktu kurang dari 2x24 jam. Hasil wawancara dengan staf verifikasi menunjukkan bahwa verifikasi dilakukan untuk memastikan persyaratan untuk klaim BPJS lengkap, penulisan resume medis lengkap terutama diagnosis utama dan tanda tangan DPJP, kesesuaian anamnesis dengan diagnosis. Rekam medis ada di ruang verifikasi rata-rata 5 10 hari. Berkas rekam medis yang disetorkan hari ini akan mulai dikerjakan keesokan harinya. Lamanya berkas rekam medis ada di verifikasi terutama untuk rekam medis pasien dengan diagnosis sulit, DPJP lebih dari satu, selisih klaim dengan biaya rumah sakit tinggi dan coding. Jika berkas klaim masih kurang lengkap maka DRM rawat inap akan dikembalikan ke ruangan untuk dilengkapi.

"Soalnya kan yang BPJS itu kita nyetor ke verifikasi, itu harus sudah lengkap disetor kesana” (B/M/26082016/1114)

\section{Faktor Kebijakan (Machine)}

\section{Kebijakan Penempelan Post It Belum Ada}

Rekam medis pasien BPJS harus lengkap terutama lembar resume medis, karena berkaitan dengan klaim. BPJS mempersyaratkan minimal diagnosis utama dan diagnosis sekunder harus dilengkapi sendiri oleh DPJP dan ditanda tangani. Dokumen rekam medis yang belum lengkap akan dilengkapi oleh kepala ruangan atau dokter ruangan. Responden D mengatakan bahwa bagian yang wajib dilengkapi sendiri oleh DPJP akan diberikan tanda post it. Kebijakan penempelan post it belum ada, sehingga belum semua ruangan menjalankannya.

"Ditandain sama post it. Nanti ditempel sama dikasi keterangan bagian mana yang belum lengkap dan dokter siapa. Nanti pas dokternya visite lagi kita ingetkan. Atau kalau gak pas visit ya dilengkapin di poli" (D/M/22092016/1200).

"Udah kita tempeli post it, bawa ke poli buat minta tandatangan” (E/B/22092016/1230).

\section{Feedback Data Rekam Medis Belum Sampai ke DPJP}

Wawancara dengan bagian rekam medis juga dilakukan untuk mengetahui akar masalah terkait keterlambatan pengembalian DRM rawat inap. Wawancara ini melibatkan kepala sub divisi rekam medis, staf rekam medis bagian assembling dan bagian pelaporan. Bagian rekam medis setiap bulannya membuat laporan lama hari pengembalian DRM rawat inap dan angka KLPCM (ketidaklengkapan pengisian catatan medis). Data ini diberikan kepada bagian manajemen dan juga feedback ke ruangan. Data belum memberikan gambaran kelengkapan catatan rekam medis setiap DPJP, hanya menunjukkan lama pengembalian setiap ruang rawat inap. Data ini juga belum pernah disampaikan ke masing-masing DPJP, karena rapat komite medik tidak dilakukan secara rutin. Rapat komite medik biasanya menunggu acara rumah sakit, sehingga lebih mudah mengumpulkan dokter spesialis. Bagian rekam medis juga sering mendapat komplain dari dokter spesialis terkait penyediaan DRM rawat jalan. Berkas ini sering tidak dapat disediakan karena saat pasien kontrol setelah rawat inap, DRM masih ada di ruang rawat inap untuk dilengkapi.

"Jarang, saya gak tau ya misalnya ada tapi saya gak ikut. Tapi selama ini kok rasanya jarang banget" (J/D/21102016/1253).

"Oohh, lama juga ya.. jadi habis opname status balik ke rekam medis seminggu?” (J/D/21102016/1253)

\section{Hasil Time Motion Study}

Time motion study dilakukan untuk mengetahui jalannya dokumen rekam medis pasien yang sudah pulang termasuk waktunya. Time motion study dilakukan dengan cara melihat dokumen rekam medis di ruangan rawat inap dan di unit rekam medis. Di ruangan rawat inap, DRM yang belum lengkap disimpan untuk dilengkapi sebelum diserahkan ke unit rekam medis. Penulis melihat tanggal pulang serta kelengkapan DRM pasien yang sudah pulang. Wawancara terhadap perawat ruangan juga dilakukan untuk mengetahui alasan DRM belum diserahkan ke unit rekam medis.

Time motion study dilakukan terhadap delapan rekam medis pasien yang sudah pulang satu hari sebelumnya di ruangan rawat inap pada tanggal 22 September 2016. Terdapat tiga rekam medis yang sudah lengkap di antara delapan rekam medis (dua pasien BPJS dan satu pasien swasta). Rekam medis yang sudah lengkap ini belum disetorkan ke rekam medis maupun verifikasi karena pekerjaan di pelayanan masih banyak, sehingga menunggu waktu yang longgar. Rekam medis yang belum lengkap antara lain karena DPJP belum menulis diagnosis sekunder, belum memberikan paraf konfirmasi lacabak, belum memberikan tanda tangan di resume medis.

Observasi juga dilakukan di ruang VIP terhadap dua rekam medis pasien pulang yang belum disetorkan, pada 
tanggal 23 September 2016. Rekam medis pertama milik pasien yang sudah pulang dua hari sebelumnya dan sudah lengkap, tetapi belum disetorkan dengan alasan belum ada waktu longgar. Sedangkan rekam medis kedua merupakan rekam medis pasien yang meninggal tanggal 19 Septeber 2016, tetapi baru mendapat tanda tangan DPJP tanggal 22 September 2016 karena DPJP hanya memiliki jadwal poli dua kali seminggu.

Observasi di unit rekam medis dilakukan untuk melihat dokumen rekam medis yang masuk pada hari itu dan menghitung lama penyetoran. Rata-rata lama penyetoran untuk pasien swasta murni yaitu 3,15 hari sampai di bagian rekam medis, sedangkan pasien BPJS 3,42 hari sampai di verifikasi. Dari data ini dapat dilihat bahwa lama penyetoran DRM rawat inap pasien swasta dan pasien BPJS hampir sama, tetapi rekam medis pasien BPJS masih harus melewati verifikasi.

\section{Identifikasi Akar Masalah}

Hasil yang didapatkan dari keseluruhan penelitian ini melalui observasi, wawancara mendalam, dan time motion study menemukan berbagai macam penyebab keterlambatan pengembalian dokumen rekam medis rawat inap ke bagian rekam medis di RS X. Selanjutnya dilakukan identifikasi akar masalah dengan menggunakan diagram fishbone dan dilakukan skoring dengan metode USG.

Tabel 1. Hasil peringkat kendala menurut pihak rumah sakit

\begin{tabular}{|c|c|c|c|c|c|c|}
\hline Faktor & Akar Masalah & $\mathbf{U}$ & $\mathbf{S}$ & $\mathbf{G}$ & Total & Peringkat \\
\hline \multirow[t]{2}{*}{ Man } & $\begin{array}{l}\text { Kurangnya kedisiplinan dokter dalam pengisian rekam medis } \\
\text { terutama resume medis }\end{array}$ & 52 & 51 & 45 & 148 & 1 \\
\hline & Beban kerja dokter dan perawat tinggi karena peningkatan BOR & 47 & 47 & 43 & 137 & 6 \\
\hline \multirow[t]{4}{*}{ Man } & Banyak dokter yang bukan merupakan home doctor & 46 & 49 & 43 & 138 & 5 \\
\hline & Perawat kurang paham mengenai kelengkapan klaim BPJS & 33 & 34 & 33 & 100 & 12 \\
\hline & $\begin{array}{l}\text { Beberapa DPJP tidak visite setiap hari, sehingga advis pulang per } \\
\text { telepon }\end{array}$ & 48 & 47 & 46 & 141 & 3 \\
\hline & $\begin{array}{l}\text { Perawat lupa mengingatkan dokter untuk mengisi resume medis } \\
\text { dan tandatangan }\end{array}$ & 50 & 48 & 42 & 140 & 4 \\
\hline \multirow[t]{2}{*}{ Material } & $\begin{array}{l}\text { Petugas khusus untuk mengantarkan DRM ke bagian rekam medis } \\
\text { tidak ada }\end{array}$ & 47 & 53 & 48 & 148 & 1 \\
\hline & Tidak ada data tentang ketidaklengkapan rekam medis per dokter & 45 & 49 & 44 & 138 & 8 \\
\hline \multirow[t]{3}{*}{ Machine } & Rapat komite medik tidak rutin & 46 & 47 & 40 & 133 & 9 \\
\hline & $\begin{array}{l}\text { Belum ada kebijakan mengenai reward dan punishment untuk } \\
\text { pengisian rekam medis }\end{array}$ & 49 & 49 & 40 & 138 & 5 \\
\hline & $\begin{array}{l}\text { Belum ada kebijakan tertulis tentang penggunaan tanda (post it) } \\
\text { untuk DRM yang belum lengkap }\end{array}$ & 41 & 40 & 34 & 115 & 11 \\
\hline \multirow[t]{3}{*}{ Method } & Alur rekam medis belum sesuai dengan pedoman Depkes & 46 & 45 & 45 & 136 & 7 \\
\hline & Ketidakpastian jam visite dokter spesialis & 48 & 48 & 40 & 136 & 7 \\
\hline & DRM pasien BPJS harus masuk ke verifikasi & 42 & 48 & 40 & 130 & 10 \\
\hline Money & $\begin{array}{l}\text { Dukungan dana untuk reward terkait waktu pengembalian DRM } \\
\text { belum tersedia }\end{array}$ & 51 & 50 & 45 & 146 & 2 \\
\hline
\end{tabular}

Sumber: Hasil Analisis, 2016

Tingkat Pendidikan akan menentukan peran seorang karyawan atau pegawai dalam melaksanakan tugasnya. Semakin tinggi ting-kat pendidikan seseorang maka akan semakin banyak peran yang diberikan kepada suatu perusahan. Hal ini selaras dengan akan ter-capainya tujuan perusahaan secara maksimal.

Tingkat Pendidikan akan menentukan peran seorang karyawan atau pegawai dalam melaksanakan tugasnya. 
Semakin tinggi ting-kat pendidikan seseorang maka akan semakin banyak peran yang diberikan kepada suatu perusahan. Hal ini selaras dengan akan terca-painya tujuan perusahaan secara maksimal. Peran yang dijalankan oleh karyawan dengan penuh kesadaran dan tanggung jawab inilih yang disebut disiplin kerja, hal itu berarti semakin tinggi tingkat pendidikan dari karyawan atau pegawai maka semakin tinggi pula tingkat disiplin kerja dalam perusahaan tersebut. $^{16}$

Bagian ini memuat data karakteristik subjek/objek/sampel/responden penelitian, hasil analisis data, pengujian instrumen dan hipotesis (jika ada), jawaban dari pertanyaan penelitian, temuan-temuan dan interpretasi temuan-temuan. Bagian ini, bila dimungkinkan, bisa dibuat grafik untuk setiap variable penelitian. Selanjutnya disajikan berturut-turut nilai statistik deskriptif (Misal; Mean, SD, Maximum, Minimum) beserta interpretasinya. Pada bagian akhir bagian ini menyajikan hasil uji hipotesis penelitian dan pembahasannya secara cukup.

\section{Pembahasan}

Hasil wawancara dan observasi di ruang rawat inap menunjukkan bahwa keterlambatan pengembalian DRM rawat inap di RS X merupakan masalah yang sudah lama terjadi. Rekam medis menjadi hal yang sangat penting terutama sejak era JKN (jaminan kesehatan nasional), karena menjadi dasar perhitungan biaya kesehatan. KLPCM RS X (kelengkapan pengisian catatan medik) di tahun 2016 sampai dengan bulan Juli 2016 sebesar 96,2\%, tetapi hal ini mempengaruhi pengembalian DRM rawat inap yang cukup lama yaitu lebih dari 7 hari. Keterlambatan ini dapat menghambat pelayanan yang diberikan terutama untuk pasien JKN, karena berkas rekam medis terutama resume medis merupakan salah satu syarat klaim BPJS. Keterlambatan klaim BPJS dapat berdampak pada terganggunya keuangan rumah sakit. ${ }^{12}$

Hasil penelitian menunjukkan bahwa faktor utama keterlambatan pengembalian DRM rawat inap yaitu faktor SDM (sumber daya manusia) seperti ketidakdisiplinan DPJP dalam pengisian rekam medis terutama resume medis, petugas khusus untuk mengantarkan DRM ke bagian rekam medis tidak ada, beberapa DPJP tidak visite setiap hari sehingga advis pulang per telepon, perawat lupa mengingatkan dokter untuk mengisi resume medis dan tandatangan serta banyak dokter yang bukan merupakan home doctor. Faktor lain tentunya juga banyak mempengaruhi keterlambatan seperti faktor method, money, material dan machine.
Hasil penelitian ini sejalan dengan yang ditemukan oleh Rachmani di Rumah Sakit POLRI dan TNI Semarang bahwa banyak faktor yang mempengaruhi keterlambatan penyerahan dokumen rekam medis (DRM) rawat inap dari bangsal ke bagian assembling. Faktor yang mempengaruhi keterlambatan ini antara lain belum adanya protap pengembalian dokumen rekam medis dari ruang rawat inap ke bagian assembling, tidak adanya petugas rekam medis di ruangan yang meneliti kelengkapan dokumen rekam medis, jarak ruang rawat inap ke ruang rekam medis yang jauh, belum lengkapnya atau tidak lengkapnya dokumen rekam medis terutama tanda tangan dokter sehingga DRM rawat inap tidak dapat diserahkan dalam waktu $2 \times 24$ jam. ${ }^{1}$

Keterlambatan pengembalian DRM rawat inap ke bagian assembling dapat mengganggu pelayanan, terutama jika dokumen tersebut dibutuhkan saat pasien kontrol di rawat jalan atau jika pasien rawat inap kembali. DPJP di RS $\mathrm{X}$ sering komplain jika saat pasien kontrol rekam medis rawat inapnya tidak tersedia, walaupun ada DPJP yang tidak mempermasalahkannya. Riwayat pasien sangat diperlukan untuk menentukan terapi ataupun tindakan kepada pasien, apalagi jika pasien memiliki penyakit kronik. Petugas assembling menilai kelengkapan DRM yang dikembalikan, jika dinilai tidak lengkap maka DRM akan dikembalikan ke ruang rawat inap untuk dilengkapi dalam jangka waktu $2 \times 24$ jam. Keterlambatan ini tentu akan mengganggu kontinuitas pelayanan.

Dokumentasi pelayanan yang buruk (penulisan rekam medis) mengurangi kualitas pelayanan dan melemahkan analisis. Penulisan rekam medis juga buruk bahkan pada pasien-pasien kritis di rumah sakit. Masalah ini berdampak pada pelayanan kesehatan dan hasil penelitian, termasuk pengembangan laporan medis.13 Menurut Pamungkas penyebab ketidaklengkapan DRM adalah kurang disiplinnya dokter dalam pengisian rekam medis. Dokter lebih memprioritaskan pelayanan sehingga waktu yang dialokasikan untuk pengisian dokumen rekam medis sedikit yang berakibat pada ketidaklengkapan dokumen rekam medis. Faktor lain yaitu: kurangnya kesadaran dokter akan pentingnya pengisian rekam medis; belum maksimalnya monitoring dan evaluasi kelengkapan rekam medis; belum adanya pencatatan KTD dan KNC akibat ketidaklengkapan DRM; form rekam medis yang terlalu banyak jenisnya; serta terbatasnya dukungan dana dari manajemen terkait kelengkapan rekam medis. ${ }^{7}$

Tingginya BOR dan kunjungan pasien di RS X berdampak pada tingginya beban kerja dokter maupun perawat, sehingga dokter lebih mendahulukan pelayanan kepada pasien daripada melengkapi rekam medis. Dokter 
sering terburu-buru saat visite karena sudah ditunggu banyak pasien di poliklinik. Temuan ini sejalan dengan penelitian yang dilakukan di RSUD Banyudono Boyolali bahwa ketidaklengkapan pengisian rekam medis disebabkan oleh tingginya beban dokter, perawat atau tenaga medis lainnya. Pasien yang banyak setiap harinya membuat kebanyakan tenaga kesehatan melewatkan untuk menuliskan nama dan membubuhkan paraf atau tandatangan di setiap formulir rekam medis. Selain itu kurangnya pemahaman mengenai pentingnya rekam medis sebagai bukti otentik pelayanan kesehatan yang diberikan kepada pasien, juga berpengaruh terhadap masalah ini. ${ }^{14}$

Pengisian rekam medis merupakan tanggungjawab setiap pemberi pelayanan kesehatan. Seorang dokter atau dokter gigi yang tidak membuat rekam medis dapat terkena sanksi secara hukum maupun etika dan disiplin profesi. Menurut Undang-Undang Praktik Kedokteran setiap dokter atau dokter gigi yang dengan sengaja tidak membuat rekam medis dapat dihukum dengan pidana kurungan paling lama satu tahun dan denda paling banyak 50 juta rupiah. Selain itu sanksi perdata juga dapat diberikan karena tidak melakukan yang seharusnya dilakukan (ingkar janji/ wanprestasi) dalam hubungannya dengan pasien.4 Pengisian rekam medis merupakan tanggungjawab setiap profesional pemberi asuhan, setiap kali melakukan pemeriksaan maupun merencanakan pengobatan dan tindakan bagi pasien. Selain itu juga dengan tingkat kedisiplinan pengembalian dokumen rekam medis yang baik, dokter juga akan merasakan manfaatnya apabila dokter sewaktu-waktu membutuhkan dokumen rekam medis tersebut. ${ }^{15}$

Rekam medis di era JKN menjadi sesuatu yang sangat penting karena menjadi penentu dalam perhitungan biaya untuk klaim. RS X sudah memiliki tim verifikasi dan rekam medis yang menilai kelengkapan rekam medis. Menurut Pujihastuti dan Sudra, terdapat 65\% rumah sakit yang belum membuat diagnosis yang lengkap dan jelas di antara rumah sakit yang sudah bekerjasama dengan BPJS. Penelitian tersebut mendapatkan hasil bahwa 30\% rekam medis yang diteliti pengisian informasinya tidak lengkap, sedangkan keakuratan kode diagnosisnya mencapai $70 \%$ yang dipengaruhi kelengkapan pengisian informasi diagnosis pada dokumen rekam medis. ${ }^{8}$

Penelitian lain yang dilakukan di RSUD dr. Slamet Garut memberikan hasil bahwa pengisian dokumen rekam medis masih belum sesuai dengan prosedur yang ditetapkan oleh rumah sakit khususnya yang berkaitan dengan identifikasi pasien, laporan penting, autentikasi dan pencatatan. Kelengkapan identifikasi pasien hanya mencapai $20 \%$, kelengkapan pengisian data laporan penting pasien sebesar $31,12 \%$, dan kelengkapan pengisian data authentikasi yaitu $83,33 \%$. RSUD dr. Slamet Garut sudah bekerjasama dengan BPJS sejak 1 Januari 2014.9 Kelengkapan rekam medis di RS X sudah baik yaitu di atas $95 \%$, karena manajemen mengharuskan rekam medis sudah lengkap sebelum disetorkan ke bagian rekam medis atau verifikasi. Hal itu berdampak pada lamanya pengembalian DRM rawat inap ke bagian rekam medis.

Bagian ini memuat data karakteristik subjek/objek/sampel/responden penelitian, hasil analisis data, pengujian instrumen dan hipotesis (jika ada), jawaban dari pertanyaan penelitian, temuan-temuan dan interpretasi temuan-temuan. Bagian ini, bila dimungkinkan, bisa dibuat grafik untuk setiap variable penelitian. Selanjutnya disajikan berturut-turut nilai statistik deskriptif (Misal; Mean, SD, Maximum, Minimum) beserta interpretasinya. Pada bagian akhir bagian ini menyajikan hasil uji hipotesis penelitian dan pembahasannya secara cukup.

Bagian ini memuat data karakteristik subjek/objek/sampel/responden penelitian, hasil analisis data, pengujian instrumen dan hipotesis (jika ada), jawaban dari pertanyaan penelitian, temuan-temuan dan interpretasi temuan-temuan. Bagian ini, bila dimungkinkan, bisa dibuat grafik untuk setiap variable penelitian. Selanjutnya disajikan berturut-turut nilai statistik deskriptif (Misal; Mean, SD, Maximum, Minimum) beserta interpretasinya. Pada bagian akhir bagian ini menyajikan hasil uji hipotesis penelitian dan pembahasannya secara cukup.

\section{SIMPULAN}

Dari hasil penelitian ini dapat disimpulkan bahwa faktor-faktor yang menyebabkan keterlambatan pengembalian dokumen rekam medis rawat inap ke bagian rekam medis di RS X sangat kompleks. Faktor yang paling dominan adalah faktor sumber daya manusia yang terdiri dari kurangnya kedisiplinan dokter dalam pengisian rekam medis terutama resume medis, beban kerja dokter dan perawat tinggi karena peningkatan BOR, banyak dokter yang bukan merupakan home doctor, perawat kurang paham mengenai kelengkapan klaim BPJS, beberapa DPJP tidak visite setiap hari sehingga advis pulang per telepon, perawat lupa mengingatkan dokter untuk mengisi resume medis dan tandatangan. Faktor lain yang mempengaruhi keterlambatan antara lain faktor method, money, material dan machine.

Keterbatasan penelitian ini yaitu kurangnya wawancara dan observasi mengenai perilaku dokter dalam 
pengisian rekam medis dari sudut pandang dokter sendiri. Sebagian besar data didapat dari perawat dan dokter ruangan, sehingga ada kemungkinan bersifat subyektif.

Possible solution yang dapat dilakukan adalah menggunakan post it untuk menandai dokumen rekam medis yang belum lengkap serta membuat kebijakan agar DPJP segera menuliskan diagnosis utama dan sekunder pada resume medis ketika diagnosis sudah ditegakkan dan memberikan tandatangan di resume medis. Kebijakan ini dibuat dalam bentuk SPO penempelan post it DRM rawat inap yang beum lengkap serta petunjuk teknis pengisian resume medis. Dengan diterapkannya solusi ini, diharapkan keterlambatan pengembalian DRM rawat inap bisa diminimalisir.

\section{DAFTAR PUSTAKA}

1. Rachmani, E. (2010). Analisa keterlambatan penyerahan dokumen rekam medis rawat inap di Rumah Sakit POLRI dan TNI Semarang. Jurnal Visikes, 9(2), 107-111.

2. Williams, F., and Boren, S. (2008). The role of the electronic medical record (EMR) in care delivery development in developing countries: a systematic review. Journal of Innovation in Health Informatics, 16(2), 139-145.

3. Menteri Kesehatan Republik Indonesia. (2008). Peraturan Menteri Kesehatan Republik Indonesia nomor 269/MENKES/PER/III/2008 tentang rekam medis. Jakarta: Kementerian Kesehatan RI.

4. Konsil Kedokteran Indonesia. (2006). Manual rekam medis. Jakarta: Konsil Kedokteran Indonesia.

5. Lihawa, C., Mansur, M., dan Wahyu, T. (2015). Faktor-faktor penyebab ketidaklengkapan pengisian rekam medis dokter di ruang rawat inap RSI Unisma Malang. Jurnal Kedokteran Brawijaya, 28(2), 119-123.

6. Menteri Kesehatan Republik Indonesia. (2008). Peraturan Menteri Kesehatan Republik Indonesia nomor 228/MENKES/SK/III/2002 tentang pedoman penyusunan standar pelayanan minimal rumah sakit yang wajib dilaksanakan daerah. Jakarta: Kementerian Kesehatan RI.

7. Pamungkas, F., Hariyanto, T., dan Woro, E. (2015). Identifikasi ketidaklengkapan dokumen rekam medis rawat inap di RSUD Ngudi Waluyo Wlingi. Jurnal Kedokteran Brawijaya, 28(2), 124-128.

8. Pujihastuti, A., dan Sudra, RI. (2014). Hubungan kelengkapan informasi dengan keakuratan kode diagnosis dan tindakan pada dokumen rekam medis rawat inap. Jurnal Manajemen Informasi Kesehatan Indonesia, 2(2), 60-64.

9. Febriyanti, R.I.M., dan Sugiarti, I. (2015). Analisis kelengkapan pengisian data formulir anamnesis dan pemeriksaan fisik kasus bedah. Jurnal Manajemen Informasi Kesehatan Indonesia, 3(1), 31-37.

10. Bachri, B. (2010). Meyakinkan validitas data melalui triangulasi pada penelitian kualitatif. Jurnal Teknologi Pendidikan, 10(1), 46-62.

11. Bustami. (2011). Penjaminan mutu pelayanan kesehatan dan akseptabilitasnya. Jakarta: Erlangga.

12. Winarti, dan Supriyanto, S. (2013). Analisis kelengkapan pengisian dan pengembalian rekam medis rawat inap rumah sakit. Jurnal Administrasi Kesehatan Indonesia, 1(4), 345-351.

13. Dharmawan, R.W., Siti, E., dan Riyadi. (2015). Pengaruh kemudahan dan kemanfaatan sistem informasi rekam medis terhadap kinerja dokter (studi pada dokter Rumah Sakit Islam Aisyiyah Jawa Timur, Malang). Jurnal Administrasi Bisnis, 27(2), 1-4.

14. Nugraheni, S., Ariani, D., dan Ruslinawati, Y. (2013). Tinjauan kelengkapan dokumen rekam medis pasien rawat inap penyakit typhoid fever di RSUD Banyudono Boyolali tahun 2012. Jurnal Infokes Apikes Citra Medika Surakarta, 3(3), 51-62.

15. Rahmadhani, I.S., Sugiarsi, S., dan Pujihastuti, A. (2008). Faktor penyebab ketidaklengkapan dokumen rekam medis pasien rawat inap dalam batas waktu pelengkapan di Rumah Sakit Umum Daerah Dr. Moewardi Surakarta. Jurnal Kesehatan, 2(2), 82-88. 